\title{
Preliminary Study of Contamination Wastewater on Environment in Slaughterhouse of Merauke City
}

\author{
Nurcholis ${ }^{1, *}$ and Dirwan Muchlis ${ }^{1}$ \\ ${ }^{1}$ Department of Animal Science, Faculty of Agriculture Musamus University, Merauke, Indonesia
}

\begin{abstract}
The purpose of this research is to know the contamination of waste water that happened in slaughterhouse $(\mathrm{RPH})$ city of merauke. Data were obtained based on surveys and field observations and the sample used was RPH water waste each in repeat as many as 6 replications. Data analysis was done descriptively by comparing the result obtained with the standard of quality which have been determined. The results showed that the contamination of waste water all exceeded the quality standard except at $\mathrm{pH}$ value. The ALT content of wastewater in RPH $2790 \times 10^{4}$ and contains E. Coli and Salmonella microbes. The high content of BOD, COD, TTS, Ammonia and microbial contamination is thought to be due to the absence of wastewater treatment installation (IPAL) at RPH in accordance with the standard. Proper handling of ammonia waste can reduce the amount of carbon in the atmosphere.
\end{abstract}

Keywords: waste quality standards; microbial contamination; slaughterhouse.

\section{Introduction}

The need of beef consumption especially beef in Merauke city is quite high based on the Livestock Service Report [2] that the consumption of beef has increased in the year that is $1.353 .240 \mathrm{~kg}$. Cattle slaughter to produce safe, healthy, whole and halal meat (ASUH) should be done in slaughterhouses (RPH). Technical requirements set forth in Permentan no. 13 / Permentan / OT.140 / 1/2010 on the requirements of slaughterhouses and meat-cutting plants is [, the location of slaughterhouses does not cause disturbance and environmental pollution. City of Merauke has 1 unit of RPH and 1 unit of poultry slaughterhouse (RPU), RPH activities city of merauke starting at $03.30 \mathrm{~s}$ / d 07.00 WIT with the amount of cutting an average of 10 tails per day this certainly contributes to environmental contamination caused by liquid waste RPH. Liquid waste in RPH generally consists of blood and rumen content, according to [6] RPH liquid waste contains blood, protein, fat and suspended solids which cause high organic and nutrient materials, high variation of species and dissolved residues this will have the effect of polluting rivers and bodies of water. The liquid wastes produced by RPH are first collected prior to disposal and utilized to ensure the contamination does not exceed the quality standard of the waste water. Wastewater quality standard materials for RPH business and or activity based on Regulation of the Minister of Environment No. 5 Year 2014 among which liquid waste has the highest levels for BOD $100 \mathrm{mg} / 1$, COD $200 \mathrm{mg} / 1$, TSS $100 \mathrm{mg} / 1$, oil and fat $15 \mathrm{mg} / 1$, NH3-N $25 \mathrm{mg} / 1$ and $\mathrm{pH} 69$ [3]. In addition there is a microbial content in RPH liquid waste derived from the contents of rumen, blood, feces meat and fat. Some of the microbes present in Beef cattle RPH include Salmonella SP [5] Basillus $S P$ in chickens [10], E. Coli [13]. Risks arising from RPH activities with wastewater management that do not have a good water management installation (WWTP) are potentially hazardous, caused by pathogenic bacteria disease and increase levels of COD, BOD, TSS, $\mathrm{pH}$ and can increase carbon in the atmosphere. Therefore, government solutions are needed to reduce the impact of this problem. Based on the above, it is necessary to conduct research related to the quality contamination of $\mathrm{RPH}$ beff cattle water in Merauke city as an effort to reduce environmental contamination.

\section{Research Method}

The sample of this research was obtained from RPH of merauke city, the analysis was conducted at Microbiology and Environment laboratory (LP - PPBBI). Preliminary data were obtained by survey and observation on Beef cattle RPH in Merauke city. Physical and chemical test of wastewater as much as 1 liter, analysis of microbiological test of waste contamination taken 0.5 liter water sample using sterile bottle. Sampling is done by purposive sampling when cutting with the number of beef cattle averaging 10 tail per day. The sample test was conducted as many as 6 replications, the data analysis was done descriptively by comparing the results with the quality raw materials that have been set in accordance with the standard.

\section{Result and Discussion}

\section{Wastewater test results}

Sampling on beef cattle RPH was done every Monday with a weekly capture interval, sample testing based on

* Corresponding author: nurcholis@,unmus.ac.id 
Ministry of Environment Regulation no. 5 Year 2014 [4] on waste water quality standards with parameters observed are BOD (Chemical Oxygen Demand) BOD, (Chemical Oxygen Demand) COD, (total suspended solid) TSS, pH, ammonia $\left(\mathrm{NH}_{3} \mathrm{~N}\right)$, oils and fats, samples of each replication given the $\mathrm{P} 1-\mathrm{P} 6$ code of the results is shown in table 1 . However in this test no oil and fat is included

Table 1. Results wastewater testing cattle cow in slaughterhouses.

\begin{tabular}{|l|c|c|c|c|c|c|c|c|}
\hline \multirow{2}{*}{ Parameter } & \multicolumn{5}{|c|}{ Sample } & \multirow{2}{*}{$\begin{array}{c}\text { Average } \\
\text { (SD) }\end{array}$} & $\begin{array}{l}\text { Quality } \\
\text { standards }\end{array}$ \\
\cline { 2 - 7 } & P1 & P2 & P3 & P4 & P5 & P6 & & \\
\hline BOD (mg/l) & 1706 & 1630 & 1520 & 1250 & 980 & 893 & $1329 \pm 975.12$ & 100 \\
\hline $\mathrm{COD}(\mathrm{mg} / \mathrm{l})$ & 2210 & 2240 & 2200 & 2310 & 2090 & 2150 & $2200 \pm 367.11$ & 200 \\
\hline TSS (mg/1) & 210 & 347 & 340 & 460 & 208 & 266 & $305 \pm 201.12$ & 100 \\
\hline $\mathrm{NH} \mathrm{H}_{3} \mathrm{~N}(\mathrm{mg} / \mathrm{l})$ & 25.3 & 22.5 & 20.34 & 12 & 19.6 & 25.11 & $20.80 \pm 17.45$ & 25 \\
\hline $\mathrm{pH}$ & 6.5 & 9 & 6.5 & 5 & 5 & 6 & $6.3 \pm 1.68$ & $6-9$ \\
\hline
\end{tabular}

The average BOD concentration in Beef cattle waste water in RPH is 13 times higher than the standard of quality of $1329 \mathrm{mg} / \mathrm{l}$. This study is lower than the results obtained by [1], which is $1451 \mathrm{mg} / 1$. BOD content in waste water can be interpreted that the higher the BOD value, the more pollutants present in the water. The value of BOD in water can be derived by several methods by using biofilter. According to [10] an alternative way can be done to reduce the levels of organic substances using anaerob-aerobic combination biofilter that has been able to reduce BOD content of 72.56-91.65\% from $1198.5 \mathrm{mg}$ / 1 to 782 , $6 \mathrm{mg} / 1$. Research conducted by [10] lowers BOD levels of RPH waste water by passing waste water on plastic bottle media that serves as a place to attach microbial aerobes and anaerobes and form biofilter that can lower BOD levels.

Mean of COD content in wastewater at RPH $2200 \mathrm{mg} / \mathrm{l}$, this result is higher than standard quality that has been determined, but this result is higher than research of [1] that is $1862 \mathrm{mg} / 1$. According to [7] COD levels in waste water at slaughterhouses in the study ranged from 1750 to $5900 \mathrm{mg} / \mathrm{l}$. High levels of COD show the high amount of oxygen needed to oxidize all the organic and inorganic chemicals in the wastewater sample. In addition to reducing the COD value in waste water can be done with microbes, according to [9] states that by embedding the microbes in gravel to form biofilter in aerobic and anaerobic conditions can reduce BOD, COD and TTS up to $65 \%$ in BOD and $29.21 \%$ in COD.

TTS level of waste water in Beef cattle RPH averaged 305 $\mathrm{mg} / 1$, this result is higher than predetermined standard quality standard. However, the results of this study were lower than [1] ie $612 \mathrm{mg} / \mathrm{l}$. High levels of TSS will cause water contamination, high TSS levels in excess of quality standards in all types of waste water allegedly due to the contents of rumen contents, stomach contents, blood intestinal contents and others. This can be seen from the color of RPH waste that is dark brown to dark red and emits a foul and fishy odor. The $\mathrm{pH}$ value of wastewater in the cow RPH shows an average value of 6.3 this value in accordance with the established standard quality standard that is $\mathrm{pH} 6-9$. The $\mathrm{pH}$ value in this study is lower than the $\mathrm{pH}$ value in [1] ie 6.60 .

Ammonia content in wastewater in RPH was $20.80 \mathrm{mg} /$ 1. The results of this study were lower than [1], which was $28.44 \mathrm{mg} / 1$. This difference is thought to be due to unequal amounts of cuts as well as the RPHs in Merauke have separate waste water reservoirs.

The total plate value (ALT) in the Beef cattle RPH wastewater is high (table 2), the high ALT value can be made possible by the use of ALT in waste water. According to [12] to improve the quality of waste can be done by utilizing biofilm and biofilter biofilter combined anaerob / aerob. Microbes are one of the keys in determining success in biological waste management.

Table 2. Microbiology Test Results RPH

\begin{tabular}{|l|c|c|c|c|c|c|}
\hline \multirow{2}{*}{ Parameter } & \multicolumn{5}{|c|}{ repeat } \\
\cline { 2 - 7 } & P1 & P2 & P3 & P4 & P5 & P6 \\
\hline ALT (colony/ml) & $4 \times 10^{5}$ & $3 \times 10^{5}$ & $12 \times 10^{7}$ & $10 \times 10^{6}$ & $34 \times 10^{6}$ & $27 \times 10^{5}$ \\
\hline E.Coli & positive & positive & positive & positive & positive & positive \\
\hline Salmonella & positive & positive & negative & negative & negative & negative \\
\hline $\begin{array}{l}\text { Psendomonas } \\
\text { aeruginosa }\end{array}$ & negative & negative & negative & negative & negative & negative \\
\hline
\end{tabular}

Microbiological testing results from Beef cattle RPH on all replicates contained E.coli bacteria while Salomella positive was found only in replicates (1 and 2). E.coli contained in RPH water waste is thought to be caused by waste discharges derived from animal waste carried by water flowing waste, these bacteria are bacteria that live in animal and human intestines. In addition, other bacteria such as Salmonella in RPH waste can contribute to environmental pollution because water is a source of contamination of salmonella typhi causing diarrhea in humans [8].

\section{Conclusion}

Based on the result of the research and discussion, it can be concluded that the value of BOD, COD, TTS, ammonia in RPH cattle waste in city of Merauke is above the quality standard that has been set in accordance with the regulation of environment minister in 2014. The high value of waste water testing other than $\mathrm{pH}$ is caused by ineffective (IPAL) that there is a need for improvement of RPH waste disposal system in Merauke.

\section{References}

1. Aini, M. Sriasih, Kisworo D. Studi Pendahuluan Cemaran Air limbah Rumah Potong Hewan di Kota Mataram. Jurnal ilmu lingkungan. 15, $42-48$ (2017) 
2. Dinas Peternakan dan Kesehatan Hewan. (Laporan Kerja Dinas Peternakan dan Kesehatan Hewan Kabupaten Merauke. Merauke, 2009)

3. Kementerian Pertanian. (Peraturan Menteri Pertanian Republik Indonesia No. 13/permentan/OT.140/I/2010 Tentang Persyaratan Rumah Potong Hewan Ruminansia dan Unit Penanganan daging meat cutting plant, 2010)

4. Kementerian Lingkungan Hidup. (Peraturan Menteri Lingkungan Hidup No. 5 Tahun 2014 Tentang Baku Mutu Air Limbah, 2014)

5. Kore. K, Asrade. B, Demissie. K, Aragaw. K. Characterization of Salmonella isolated from apparently healthy slaughtered cattle and retail beef in Hawassa, southern Ethiopia. Preventive Veterinary Medicine. 147, 11-16 (2017)

6. Kundu.PA, Dabsarkar. S, Mukherjee. Treatment of Slaughter House Wastewater in a sequencing Batch Reactor, Performance evaluation and Biodegradation Kinetics. Hindawi Publishing Corporation, BioMed Research International Article ID134872 (2013)

7. Loganath R and Mazumder D. Performance Study on Organic Carbon, Total Nitrogen, Suspended Solids Removal and Biogas Production in Hybrid UASB Reactor Treating Real Slaughterhouse Wastewater. Environmental Chemical Engineering. 18, 30276-8 (2018)

8. Makendi. C, Hale.C, Page .A. J, Wren.B. W, Phuong T. L. T, Clare.S, Hunt.M, Goulding.D, Klemm.E.J, Pickard.D, Okoro.C, Thwaites.GE, Thompson N.P.H, Weill.F.X. A Phylogenetic and Phenotypic Analysis of Salmonella enterica Serovar
Weltevreden, an Emerging Agent of Diarrheal Disease in Tropical Regions. Plos Negleted Tropical Disease. 1-19 (2016)

9. Parasmita B.N, W. Oktiawan, M. Hadiwidodo. Studi Pengaruh Waktu Tinggal Terhadap Penyisihan Parameter BOD5, COD dan TSS Lindi Menggunakan Biofilter Secara Anaerob-Aerob. E journal Undip. (2012)

10. Tantrip. R dan Thungkao. S. Isolation Proteolytic, Lipolytic, and Bioemulsifying Bacteria for Improvement of the Aerobic Treatment of Poultry Processing Wastewater. African Journal of Microbiologi Research 5, 30 (2012).

11. Susanto H, Budijono. M, Hasbi. Peningkatan Degradasi Polutan organik Air Limbah Rumah Potong Hewan dengan Proses Biofilter Kombinasi AnaerobAerob Bermedia Botol Plastik Berisikan PotonganPotongan Plastik Untuk Media Hidup Ikan Budidaya. Fakultas Perikanan dan Ilmu Kelautan UNRI. Pekanbaru. (2013)

12. Tian Q, Ong S K, Xie X, Li F, Zhu Y, Wang F R, Yang B. Enhanced phosphorus recovery and biofilm microbial community changes in an alternating anaerobic/aerobic biofilter. Chemosphere 144, 1797-1806 (2-16)

13. Um.MM, Barraud.O, Kérourédan.M, Gaschet.M, Stalder.T, Oswald.E, Dagot .C, Ploy.MC, Brugère $\mathrm{H}$, Bibbal D. Comparison of the incidence of pathogenic and antibiotic-resistant Escherichia coli strains in adult cattle and veal calf slaughterhouse effluents highlighted different risks for public health. Water Research. 15, 30242-6 (2015) 